\title{
Improving water governance in Brazil: an organisational memory approach
}

\author{
Danilo Rothberg \\ Joanne Garde-Hansen
}

${ }^{I}$ UNESP, São Paulo State University, Bauru, SP, Brazil.

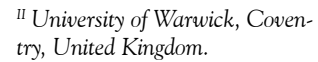

\begin{abstract}
Brazilian river basin committees are a democratic innovation increasingly studied throughout the world as a positive example of water governance, with some limitations. In our two-year research project (2018-2020), we aimed at activating, preserving and circulating narratives and stories from the participation of the various social, economic and political actors in the Upper Tietê River Basin Committee (São Paulo), in order to gather organisational memories. Our interview data bring lessons applicable to contexts with similar governance systems and others beyond, by suggesting how democratic, participatory arrangements can be improved as strategies that a society can explore in the process of learning how to cope with the effects of climate change, including the threat of water scarcity that grew in the metropolitan region of São Paulo after 2014. Interviews point to the need to clarify the roles of the committee and its members before society, to strengthen authority and legitimacy.
\end{abstract}

Keywords: Water governance; political participation; organisational memories.

São Paulo. Vol. 24, 2021

Original Article

DOI: http://dx.doi.org/10.1590/1809-4422asoc20200211r3vu2021L4AO 


\section{Introduction}

Brazilian river basin committees are a democratic innovation increasingly studied throughout the world as a positive example of water governance, with some limitations. The scenario of water scarcity grew from 2014 in the metropolitan region of São Paulo and brought new challenges to this model of governance. In that year, the region faced the driest summer in 30 years, and the temperature was $3^{\circ} \mathrm{C}$ higher than the average registered since 1943, when records began (JACOBI; CIBIM; SOUZA, 2016). Although there was evidence suggesting that the phenomenon should be approached differently, in the context of the necessary efforts to climate change adaptation, the governance structures in place, including the Upper Tietê River Basin Committee, were not sufficient to prevent water rationing, even when crucial reservoirs reached unprecedented low levels (MARTINS, 2014).

In our two-year research project (2018-2020), we aimed at activating, preserving and circulating narratives and stories from the participation of the various social, economic and political actors in the Upper Tietê River Basin Committee (São Paulo), in order to gather organisational memories. These memories, we contend, connect normativities built in the past, frame future expectations and act as valuable assets for improving water governance in the present context of climate change adaptation, in which events such as the 2014-2015 water crisis should be considered as an indicator of a sustained threat.

In what follows, we present and analyse the research results, after conducting, during the year of 2019, interviews which had the goal of eliciting organisational memories of 45 members and former members of the committee, selected because of their distinct experiences of participation in that deliberative sphere. In this paper, we present perspectives, narratives and memories retrieved from those interviews. Our purpose is to bring lessons applicable to contexts with similar governance systems and others beyond, regarding perceptions which connect past, present and future towards how to overcome the most pressing obstacles faced by the committee to fulfil its duties and members and society's expectations. This goal becomes relevant as the availability and accessibility of the past - reflections, memories and narratives - also determines whether experiences are forgotten, and with these, therefore, preparedness may be lost. We analysed, in particular, how the committee retrospectively considered its limitations in the efforts to deal with the water crisis in the São Paulo metropolitan area in 2014-2015.

Although Brazilian river basin committees manage a small and variable fraction of the public budget, their political legitimacy is actively sought when it becomes imperative for an elected government to obtain support for controversial decisions posing significant impacts on environmental sustainability. However, the literature suggests that the committees face many challenges, including the deficit of participation of city governments and society, the requirement to develop a more effective articulation with the other actors of water governance, particularly in the context of the São Paulo metropolitan area, in the case of Upper Tietê River Basin Committee, and the need for envisaging how they can contribute to climate adaptation.

In fact, as the São Paulo state government was reluctant to include the committee 
in the decision-making process during the water crisis, how to make feasible the roles of such a design of water governance proved challenging. Its agency, as the capacity to secure the legitimacy required for its operation, seemed to be in need of strengthening. As we shall see in our findings, the organisational memories we collected corroborate such challenges and suggest ways to deal with them in order to improve decision-making.

We found a consensus around the need to constantly reconstruct the legitimacy of the committee's performance, in times of crisis, which in turn requires increasing the visibility of their decisions before society, to widen participation. Moreover, its members should have their roles clarified, if they wish to strengthen their representativeness.

\section{Literature review}

The literature on the advantages of collaborative governance practiced when government, businesses and society are organized in a systematic and regulated manner in participatory arrangements highlights several factors. Firstly, there is the possibility that policy-making will benefit from the perceptions of various sectors affected, which may have a valuable understanding of the situation and offer quality feedback. Secondly, the literature points to the greater propensity of the affected sectors to collaborate with the implementation of a policy, since they cease to be mere spectators of intrusive actions and, thus, tend to feel co-responsible for successes or failures. Thirdly, there stands the achievement of more legitimacy and transparency of the process, which in turn contributes to the different actors become to feel more empowered, which is in itself a driver of efficiency of public policies (CASTREE et al., 2009).

The Brazilian river basin committees offer solutions designed to maximise the advantages of governance arrangements applied to environmental sustainability, in addition to seeking to minimise their disadvantages (commented ahead). Its decision-making architecture, legally defined, makes it easier for them to constitute what Abers and Keck (2013) call 'practical authority', characterized by the legitimacy necessary for shared decision making that generates effectiveness in the implementation of the agreed actions. The Brazilian river basin committees innovate because they grant equal decision-making power to participants from different sectors. They have fixed procedures to regulate communicative action in periodic meetings, which occur with specific agendas publicised in advance. They articulate themes around a political agenda in order to provide a wealth of flows of expertise, information and knowledge in the production of responses to build capacity. Moreover, they create a multitude of remembering participants.

By doing so, the committees bring the potential of eliciting adaptation to changing scenarios in the exploration of water for multiple uses, which include the effects of climate change and economic performance requirements (see ENGLE; LEMOS, 2010; ABERS; KECK, 2013; BARBOSA; MUSHTAQ; ALAM, 2017). These are advantages that can be translated into possibilities to overcome the distance caused by traditional forms of democratic representation, in particular in the water management, increasingly subjected to challenges such as climate change (SUSSKIND, 2013). However, the institutional design should be taken as just a starting point for improving water governance. 
Social actors need then to use it aiming at building practices which lead to greater authority and legitimacy, according to Abers and Keck (2013, p. 22), who emphasize the relevance of transformative agency as creative capacity in that process: "having good ideas is not enough if they are not translated into material resources and relationships through which actors can transform ideas into working organizations, concrete activities, and enforceable decisions".

The primary functions of a Brazilian river basin committee are the elaboration, approval and monitoring of the execution of statutory water resources management plans, which determine legal aspects such as "goals of rationalization of use" and "guidelines and criteria for charging for the use of water resources" (BRASIL, 1997). Their inception has been progressing mostly since the national law was passed in 1997 within the scope of each one of the 27 federative units in Brazil, and great expectations have been raised over their potential to democratise power relations (CAMPOS; FRACALANZA, 2010). In 2020, there were 236 committees across the country, 21 only in the São Paulo state (ANA, 2020). The first Brazilian state to have them was São Paulo, where the law responsible for its creation dates back to 1991, prior to the national law (SÃO PAULO, 1991).

The experience of many parts of the world with participatory arrangements in water management has shown how the inclusion of a diversity of social, economic and political actors in the decision-making processes can improve water access, supply and distribution with social justice (PAHL-WOSTL, 2015; NONES, 2016). However, diversity and inclusion have to be worked at through reflective and critical narration and re-narration of past water debates and experiences. In fact, there is a voluminous literature on the improvement needs of the committees, which describes aspects such as the lack of commitment to the agenda of the regular meetings, which would cause high absenteeism, particularly at the levels of municipal governments and the members' lack of understanding about their roles; the capture of decisions by representatives of the state level of government and the disproportionate influence of the interests of economic sectors; and the unpreparedness of social organisations to participate in decision-making and the use of technical expertise by government representatives at the state level to underestimate interests voiced by social organisations.

In particular, the analyses indicate that the river basin plans prepared by the committees do not always facilitate horizontal articulation and water security planning, which could be tackled by the expansion of society's engagement in the shared decision-making process (SANTOS et al., 2020). There is a lack of support from the state government, appropriate management tools are scarce, and participation of municipal and state public authorities and civil society has been low in the committees (TRINDADE; SCHEIBE, 2019). Often "a weak capacity for organizing and mobilizing civil society is observed" (JACOBI; CIBIM; SOUZA, 2016, p. 437).

In the case of the São Paulo metropolitan area, the committees are expected to embrace a larger role in the context of the metropolitan management and collaborative governance models facing climate change (JACOBI; CIBIM; LEÃO, 2015; JACOBI; NASCIMENTO, 2016). 
The Upper Tietê River Basin Committee was created by the State Law 7663/1991, but the first board was elected and took office only in 1994. The Upper Tietê watershed area is $5,868 \mathrm{~km}^{2}$ (3.7 times bigger than Greater London, for instance), with a population of 20 million inhabitants, and remaining natural vegetation occupying approximately $30 \%$ of the area. It is the largest economic hub in the country, housing the headquarters of the most important industrial, commercial and financial complexes in the country. It is, among the 236 basin committees operating throughout the country, the one that manages the most populous area, and for this reason it is considered by many of its members as the one that faces the most unique challenges.

As of 1997, five subcommittees were created, which co-manage sectors of the basin. The committee is a public body subordinated to the State of São Paulo, with consultative and deliberative roles. Like the other river basin committees in State of São Paulo, it is made up of representatives from three segments: state government, municipalities and civil society (including business associations, non-governmental organisations, universities, community organisations etc), with equal participation from 18 members per segment, appointed by the sectors they represent to exercise fixed terms of two years. The deliberations are taken at meetings held every two months, on average, while there may be more frequent meetings of subcommittees, which manage sections of the watershed (or catchment/basin), and of technical groups, which analyse specific issues with the expertise of guests with permanent seats. The agenda of the meetings is publicized in advance, so that the representatives of each sector can discuss with their respective sectors the political positions they should deem most appropriate. There is no legal impediment to reappointment thus creating the conditions for members having long term organisational memory, and there are representatives of society organisations that remain for more than three terms.

The representatives of the state government and municipalities tend to be changed according to the length of the terms of governors and mayors (elected for four-year terms). An analysis of the committee's performance over the years since its creation suggests that there is a need for more integration of its lines of action with the other actors in the metropolitan management, so the projects funding could be deployed in closer articulation with them (ALVIM; RONCA, 2007).

The Upper Tietê River Basin Committee tends to be hampered by the shortcomings affecting the governance system as a whole. As any committee of that system, it is expected to allow social actors "to act, in principle, having a directive on their role, responsibilities and attributions in order to neutralize predatory practices oriented by economic or political interest", according to Jacobi, Cibim and Leão (2015, p. 36); but, in the case of the Upper Tietê committee, "this does not happen, since we note a fragile capacity to organize and mobilize civil society". About that committee, studies have shown "a very complex picture, mainly with regard to the little effectiveness of the decisions and the representation of the civil society" (JACOBI; CIBIM; LEÃO, 2015, p. 36), despite the fact that national and state law place it in the centre of the decision-making process (JACOBI et al., 2013; JACOBI; CIBIM; SOUZA, 2016). 
Actually, these studies suggest that the Upper Tietê River Basin Committee has been showing, since its creation in 1991, problems that throughout its history have compromised the exercise of agency as a creative capacity to obtain the legitimacy subsumed under the practical authority (ABERS; KECK, 2013). Back when the new policy was passed, public managers and civil society living in the upper Tietê basin area participated very little in the approval of the legislation, "once broader social sectors were not mobilized in the process of discussion (of the law)", according to Jacobi, Cibim and Souza (2016, p. 432). Those would be mostly problems of representativeness (social sectors sometimes do not feel well represented), efficiency (its internal processes do not always work properly), efficacy (some social sectors resist the implementation of change) and effectiveness (even when properly implemented, some decisions tend to not render the expected effects).

An analysis of the committee's performance over the years indicated that its plan of action for the period from 2010 to 2015 presented "a limited approach to guidelines for overcoming the conflicts between the various sectors of water users" (SANTOS et al., 2020, p. 8). When the water crisis broke up in 2014-2015, although the Upper Tietê River Basin Committee was expected to help to fulfil the right to information and transparency rules about what was happening, it proved ineffective (EMPINOTTI; JACOBI; FRACALANZA, 2016; MARTINS, 2014). In this sense, the management of the 20142015 water crisis in São Paulo can be taken as an indicator of how those difficulties persist through almost 30 years and 12 different boards, each one elected for two-year terms, and therefore should not be neglected, as our findings suggest. The persistence of such obstacles would occur despite the fact that the committee had many experienced members - formerly in high ranks in public office, government-owned companies or NGOs and with a solid reputation built over many years - in the position of presidency, vice-presidency and executive secretary.

\section{Methodology}

Our qualitative research methodology included the deployment of strategies inspired by studies of social memory to reactivate, recover and recirculate organisational memories from Upper Tietê River Basin Committee members and former members, in order to generate knowledge that could be useful to inform the performance of public managers in institutional spheres of water governance. In the context of the studies of social memory adding to socio-ecological research, it is assumed that the activation, recovery and circulation of memories and personal perspectives on the management of collective efforts to climate change adaptation can contribute to the development of community resilience (see WORCMAN; GARDE-HANSEN, 2016; GARDE-HANSEN; MCEWEN; HOLMES; JONES, 2017; GARDE-HANSEN; MCEWEN; JONES, 2015).

From January to December 2019, we conducted semi-structured interviews with 45 members and former members of the three segments that comprise the Upper Tietê River Basin Committee. The interviewees were chosen according to their representativeness, assessed according to the length of time they have/had been part of the committee and/ or relevant public management bodies in water management, in addition to attendance 
at committee meetings. Those who were active over a longer period and more present were preferred because they were considered a living archive of policy and practice. The interviews were videotaped and are available, both in full and edited by themes, on a web page (http://www.faac.unesp.br/altotiete) funded by the project research grant and produced as a resource of science popularisation, linked to the official website of the committee. The average recording length of the interviews was 40 minutes. Versions lasting 20 minutes, on average, were made by the project team, along with thematic videos of around 15 minutes.

At the time of the contact for scheduling the interviews, the interviewees were reminded of the legal attributions of the committee and the challenges usually cited in the literature for compliance with those duties, in addition to questions that sought to encourage the recall of experiences and situations where the challenges were or were not well addressed, as well as personal perspectives and anecdotes on appropriate ways to solve them, related to their memories.

The deep-dive interviews we conducted sought to bring to light the crucial aspects of relevant experiences, recovered from memory by appropriate incentives and offered in the form of personal-professional narratives. This content was organized according to an editing logic that allowed us to draw interpretative routes to contrast the individual and collective dimensions of water governance memory and to emphasize the ways in which the members of the river basin committees dealt with the challenges in an institutional, participatory architecture (ASSMANN, 2010; KANSTEINER, 2002). Langenmayr (2016) situates studies of memory in organisational contexts in a way that proved useful to inspire our research on the trajectory of water governance structures, particularly when the goal is to understand how the narrative dimensions of individual and collective memory relate to the wider institutional framework of public management (i.e. structure and agency).

Memories were sought in our interviews by a strategy that, inspired by the constructivist paradigm (LUHMANN, 2013; FELDMAN; FELDMAN, 2006), considered them as connections between the committee's past (capacity built over time to deal with management challenges), the present (application of management resources built over time) and the future (possibility of deployment of those resources, determined by their expected adequacy to face the (un) expected challenges).

Therefore, interviewees were encouraged to develop narratives following two lines of remembering: the first about their experiences going through the debates and decisions facing water governance problems, and the second about their assessment in hindsight on whether the strategies adopted were adequate or not, and how they could be improved, in the context of the advantages and disadvantages imposed by the participatory architecture of the committees.

Under the study of organisational memory according to the constructivist perspective, the object taken into consideration is remembering as part of a practice made up of four components: "practical understandings, rules, teleological structuring, and general understandings" (LANGENMAYR, 2016, p. 60). Practical understanding is related to the construction of memory as an explanatory key; rules refer to its normative role, of 
behaviour orientation; teleological structuring is ordered according to the requirement to make it possible to interpret the next steps towards the organisation's purposes; general understanding allows actors to make sense of events and to connect them to previous knowledge and memories, even though memories are simultaneously acting in the full reconstruction of events. The memories of the interviewees in our research exercise the function of connecting the past, through reconstruction, to the future. For the overlapping is vast: "the organisation needs to construct a past, as well as a possible and therefore expected future, in order to choose one alternative out of the totality of possible alternatives", indicates Langenmayr (2016, p. 69).

Consequently, due to their mandates within a fixed duration, the members of the committee strive to guide their present performance by constantly drawing links to the past (seeking to have knowledge and learn from previous representatives) and the future (seeking to position themselves in an appropriate way to maintain a coherent political representation), albeit this also suggests a conservative approach to decision-making. In this sense, their ability to act is partly determined precisely by the ability with which they can look at the past and extract from it the guidelines for the present time action, in order to achieve the expected result in the future (all of which suggests a need for a controllable narrative arc).

Organisations need a functional memory "to assure themselves about their own present, on which they constitute themselves, and their future, by drawing back to their past and decide in the present on the basis of an unknown future" (LANGENMAYR, 2016, p. 73). The interviewees' memories in our research were interpreted as stories and narratives that present clear causal connections anchored in norms. They are perceptions accumulated over time from experiences assessed against various normative implications.

Walsh and Ungson (1991, p. 61) defined organisational memory as "stored information from an organization's history that can be brought to bear on present decisions". Once memories become more relational, changeable and social, as Casey and Olivera (2011) note, they should be one of the key focuses of research on water governance.

Why might seeking narratives and stories be taken as a valuable asset to improve water governance in the context of organisational memory and forgetting in the committees? Remembrance within organisational memory helps to uncover lines of action left behind, traces of experiences, dynamics of power and relationships, and how individuals and groups maintain memory (see CASEY; OLIVERA, 2011, NISSLEY; CASEY, 2002). "Every decision marks a certain set of distinctions that have led to this decision and not to a different decision and therefore frames future decision-making", according to Langenmayr (2016, p. 77-78). Forgetting implies neglecting certain narratives in the present, which can, however, be resumed later or not incorporating new knowledge at all. "This indicates that the main function of memory is not remembering, but the mediation between what needs to be actualized and what can be forgotten by the organization", and in this process "an organization is actively able to frame itself and its future because every subsequent decision takes the present decision into account" (LANGENMAYR, 2016, p. 78-79). 


\section{Results and discussion}

Interview data helps us to bring recommendations on the exercise of the committee's roles, particularly regarding the memories of the 2014-2015 water crisis, and the contribution of the committee as a vehicle for participation in the management of climate change adaptation, with which the water crisis would be possibly linked. The testimonies are presented and commented on in this section and demonstrate what the participants wanted the researchers to carry forward as their acts of witnessing and experience. All interviewees were in their current representative terms of committee membership at the time of the interview, except when stated in footnotes.

From the interviews, there emerges the perception that the committee, due to the limits of capacity of performance imposed by the legislation of its creation, did not act adequately when facing the water crisis: "There was no previous discussion on the situation (of the crisis) and no pragmatic discussion on the routes to be followed", says one representative from the industrial sector: "The management plans produced periodically by the committee have a generalist view and have not been able to consider ways of preventing the crisis. They cannot be invoked as the voice of the committee in situations that require quick and objective responses" (FSMF, society representative, industrial sector). Another stated: "It stopped raining and we have no plan B for emergencies, despite the engineering works decided in the cabinet" (SW, municipality representative). While another argued: "The committee's participation (in the management of the water crisis) was negligible. It was an absence, reflecting the little importance given to this forum of discussions on something that was fundamentally its core, the access to water in a crisis situation" (AP, society representative, professional association).

These internal criticisms suggest how the legal bases of the committee need to be better defended. While at their beginning the committees represented important democratic innovations, according to the authors reviewed above, the water crisis around the time of our research affords critical reflections on the need for permanent reconstruction of their 'practical authority' (see; ABERS; KECK, 2013; JACOBI; CIBIM; SOUZA, 2016; JACOBI; CIBIM; LEÃO, 2015; EMPINOTTI; JACOBI; FRACALANZA, 2016; SANTOS ET AL., 2020). Among the recommendations raised by the interviewees, recurring themes were: a) demands to improve the relationship between the sectors represented; b) the need to increase the publicity of the committee's decisions; and c) to attract and expand social participation.

These aspects, which run through the committee's trajectory over time, included concerns about the demand for equalization between the various forms of water knowledges and the adoption of appropriate communication approaches that must be multi-directional: "Technical information that is important for a management process should be valued. Within the committee there is a difficulty in doing this. There is a problem of communication between people of different expertise" (RH, society representative, public university). Emotional connection and a shared vocabulary for water crises were key: "What is the language for approaching others, getting closer and gaining 
their trust? I don't know how to do that. For each sector, there must be an appropriate form of communication" (HS, water management foundation representative). While another member noted: "Engagement [...] depends on motivation, how they feel part of the process" (FSMF, society representative, industrial sector).

These comments place the potential reach of the committee precisely at the crossroads between the perception of the lack of communication experienced by some of its members in the past and the expectations they place on the performance of this water forum in the future, while working through recent water crises. The interviewees sought to develop a performance capable of remedying the long-standing problem of remembering their respective roles, knowledge communication and their relationship not only within the committee, but also from the committee to the society. This is a problem pointed out by the literature reviewed above as one of the obstacles to its efficiency in the articulation between various social sectors (CAMPOS; FRACALANZA, 2010; JACOBI; CIBIM; LEÃO, 2015).

Key to remembering governance of a water crisis was to recognize those forgotten in a supposedly representative committee:

A very important segment is missing, which is the housing movements.
We have the problem of the squatter settlements in areas around
water springs, and that population needs to participate in order to
understand the importance they have in the preservation and recovery
of water resources (VF, representative of society, non-governmental
environmental organisation).

Moreover, "there are decreasing participation rates of some social sectors. I think it is also related to the social moment the country is experiencing" (HRF, state government representative). Furthermore, "there are problems of representativeness of the State level in the committee. In the municipalities level, there is disinterest. From civil society, there are very atomized representations, of very specific groups" (ET, state level representative). While another member noted: "I see as low or non-existent the participation of the rural sector and social organisations that could help to think of water use in another way" (HS, water management foundation representative).

Experienced participants who have witnessed various situations over time, in which the committee's performance was limited by the complex participatory architecture, put forward what they consider a realistic view of the constraints that cannot be ignored in the committee's path towards the future: "The committee has a bold and idealistic proposal, as it puts all interests on the table in search of solutions. But it does not have governance over the totality of the resources needed for that" (RAB, water management foundation representative). Thus, the committee is tied to its own organisational memory and this can prevent a fast and effective response to water crises, as one member claimed: "In general, the committees have strong deliberative power, but low executive power. You have the power to decide what to do, but you don't have the money to do it. They are paper tigers. Powerful, but harmless" (JGLC, state level representative). While another 
stated: "Regulations are good to prevent money from going down the drain, but at the same time they block the process a lot, and it is very difficult for city halls, society and community organisations to have access to the resources" (MD, society representative, non-governmental environment organisation).

Some recognise, however, advances in terms of managerial capacity. "The committee has gone through a process of ups and downs. Currently, in general, there is a professionalization and recovery of the initial objectives". (HRF, state government representative). Others propose the need for the committee to look at the national political landscape, although it is not clear how it could be made: "We have to pay attention to the themes of national politics, in Congress. The committees look only at their basin and do not interact" (MM, representative of society, representative of society, non-governmental environmental organisation).

Here we notice that the recommendations go beyond the scope of possible solutions within the internal management of the committees, and reach the eventual need for changes in the very legal system (its organisational founding memory) that determines the limits of their performance. The memories and reflections of some more experienced members place the future of the committee in close dependence on changes in the terms of its creation 30 years ago, raising debates in the state Legislature.

These are profound contradictions: many interviewees acknowledge that the committee carries legal duties in many battle fronts, and this should render it capable of addressing the water crisis in relation to climate change adaptation. However, in the present time, the committee's capacity would not be fully developed yet, mainly because the future which those legal duties point to is not clearly outlined, as we note from these statements: "To the extent that (the committee) focuses on aspects that limit the use of water resources in the region, it is a way of tackling climate change on the side of scarcity" (HRF, state level representative). Clearly, climate change is not forgotten but rather it is implicit and abstract: "All (committee) projects have something to do with climate change, even if people don't write those words" (DHR, state level representative). While another member noted: "[Climate change] should be a priority axis, but we have not seen it become a concern in the committee's day to day' (JLA, state level representative, public research institute).

These statements suggest that there is a perception among the interviewees that the climate change adaptation involves strengthening the specific role of the committee oriented in this futures direction, but the present time does not necessarily offer opportunities for the preparation of this water forum for that purpose. The need for strengthening the committee's practical authority and its legitimacy, already pointed out in the literature, becomes even more vital for it to perform adequately in the face of climate change (CAMPOS; FRACALANZA, 2010; ENGLE; LEMOS, 2010; ABERS; KECK, 2013; TRINDADE; SCHEIBE, 2019). This negative perception may have been partly influenced by how the committee's performance in the water crisis in São Paulo in 20142015 was felt collectively: 
There is a consensus among society on the subject, but there is a lack of perception that it is affecting our lives and will affect it more and more. São Paulo, for example, never recovered the levels of water springs again, and there is no forecast of recovery. I am concerned about how the committees are handling this. The Upper Tietê Committee was excluded by the State and did not participate in the discussion of the water crisis, and it was only after much fighting that it was included in the discussion (FAS, society representative, professional association).

This interviewee added that the "fight" to be included was basically the pressure exerted by the committee leadership pledging a seat in the commission created by the state government to discuss solutions. However, that seat meant only that the committee's representative was allowed to observe how the decisions were being taken predominantly by state officials, which goes against the very governance system ideals.

Two statements suggest that a quick answer would not be supported by the administrative capacity of the committee in the present time, given the configuration of the bureaucracy of its internal processes, which are anchored in remembering its organisational memory rather than adapting to an uncertain future:

The committee should be more aware of the consequences of climate change for water resources and establish guidelines for how to appropriate, use and protect them. It cannot fail to take it into account when making the river basin plans, which must have a 20,30-year vision of the future. But I do not believe that the committee is an adequate forum for a broader discussion on issues regarding climate change. (LFC, municipality representative)

Yet, says another,

The committee's response time is very slow. It is a system that does not work for times of crisis. When it comes to climate change and critical droughts like the one in São Paulo, the committee takes three to six months to be able to give an adequate return. In times of crisis, it is an inadequate time to make decisions and create density in the process. (JGLC, state-owned water company representative)

This weakness, identified in the testimonies given by experienced actors, corroborates aspects stressed by studies that have assessed the governance system's lack of capacity to react noted since the 2014-2015 water crisis. "Despite (...) having a law that implements an integrated, participatory and decentralized water management system", suggest Jacobi, Cibim and Leão (2015, p. 29), "the actions coordinated by the government of the state of São Paulo, the public water company Sabesp and the water management system in the Upper Tietê river basin have not been able to avoid the serious threat of water shortages in the region".

Furthermore, the water crisis was initially dismissed as an unexpected and transient 
incident, despite previous evidence suggesting otherwise (JACOBI; CIBIM; SOUZA, 2015). However, a more systematic approach, built on the awareness of climate change adaptation, did not arise from the committee, although it could be, due to its participatory design, more sensitive to the influence of the diversity of sources of information flowing through its various participants. In fact, the water crisis was hardly seen in the context of climate change, thanks in part to the committee itself, as suggested by these other statements: "Construction works must be interrupted in cities where there is water rationing. But the real estate and building sectors do not yet feel that connection (with climate change) much" (LS, society representative, construction industry). "I still see a lot of scepticism about the risk of water scarcity. We got to a serious level back there, but that didn't raise that much awareness" (EJB, municipality representative).

These two statements identify a widespread forgetting, underlying the unlikeliness of many social sectors to accept the reality of climate change.

\section{Conclusions}

This paper presented results from our study of organisational memory in which interviews with 45 members and former members of the Upper Tietê River Basin Committee were carried out from January 2019 to January 2020. We elicited perspectives that operate connections between norms set in the past and views that shape, in the present, expectations about dealing with future challenges, in a context of climate change uncertainty and risk. The organisational memory research methodology proved to be valuable, as it was able to reveal insights and reflections on opportunities for improving governance systems that adopt participatory formats, such as the Brazilian one and beyond, as one of their main challenges consists in increasing representativeness and decision-making efficacy (PAHL-WOSTL, 2015; NONES, 2016).

In this final section, we summarise the results and key findings.

Many respondents recognised the limitations experienced by the committee in managing the 2014-2015 water crisis. Among the recommendations they made to tackle the difficulties, it is the permanent reconstruction of the committee's practical authority (ABERS; KECK, 2013), that is, the legitimacy and relevance of its performance, in times of crisis. This, in turn, should require increasing the visibility of their decisions before society, in order to attract and expand social participation, which places the demand for communication approaches compatible with that purpose.

Regarding management efficiency, the organisational memory that our study brought to light suggests that it is necessary for members to be clear about their roles, in order to improve the representativeness of their respective social, economic and political sectors. This key finding corroborates opportunities for improvement pointed out by previous studies (JACOBI; MONTEIRO, 2006; JACOBI; CIBIM; LEÃO, 2015). Furthermore, it reaffirms the relevance of the online repository of organisational memory that we created in the research project of which this article is one of the results, available at http:/www. faac.unesp.br/altotiete, which may serve as a source of parameters and guidance for the 
performance of present and future members. Also, we point to the need of exchanging learning and experiences between committees in other river basins, which can produce different responses to similar challenges.

The need for more participation of sectors that are currently absent or rare in the committee, such as the housing movements, rural sector and NGOs was also emphasized by some interviewees. These sectors, in addition to the municipalities, which would have little interest in participating, should be called upon through strategic actions.

We also found that the bureaucratic procedures of the committee, although seen as necessary by some interviewees, were considered an obstacle to the effectiveness of its performance, due to the long time required for decision making, incompatible with the urgency needed in times of crisis.

It should be noted that we did not identify significant differences between the various sectors represented in the committee. In fact, we noted a convergence of views in the overall assessment.

An almost consensual aspect among the interviewees was the need for the committee to reflect more intensively on the relationship between climate adaptation and the water management policies for which it is co-responsible. One aspect that compromised the consensus in this respect was related to the distrust of its own competence: some questioned if the way the committee is legally structured and usually works would be appropriate to deal with such challenge. This finding, in turn, suggests the demand for legal reform, a path we could not explore since it is beyond the limits of our research design.

Scepticism and ignorance, denial and everyday forgetting of the effects of climate change would probably be aspects that would hinder the committee's internal organisation, considering its legal and political foundations built over its 30 years of operation. The recovery, reactivation and circulation of memories within the river basin committee brough light far more over the acknowledgment by committee members of the challenges to be deal with, than the committee's capacity to face those challenges.

Our research process for activating, preserving and circulating narratives and stories from the participation of the various social, economic and political actors in the Upper Tietê River Basin Committee (São Paulo) sought to uncover the organisational memories. We found that these memories were both conservationist of the founding principles and 30-year history of the committee, while simultaneously critical of this history that both includes and excludes, remembers and forgets. Our findings suggest that organisational memory operates as a way of making the future of the committee more certain than the future of water availability. Members were candid in their reflections on what the committee forgets as well as wider society thus circulating new stories and experiences as organisational memories that seek to improve water governance (LANGENMAYR, 2016). How far the river basin committee reflects upon the interviews produced by this research is to be seen.

\section{Acknowledgements}


We thank Fapesp (São Paulo Research Foundation, grant 2018/02270-9) and CNPq (National Council for Scientific and Technological Development, grant 305689/2019. 3) for the funding provided, and the Upper Tietê River Basin Committee for all the support offered to us, especially from Amauri Pollachi, Hélio Suleiman, Luiz F. Carneseca and Ana Sedlacek. Interviews in full and edited thematic videos can be found at the project website: http://www.faac.unesp.br/altotiete.

\section{References}

ABERS, R. N., KECK, M. E. Practical authority: agency and institutional change in Brazilian water politics. Oxford: Oxford University Press, 2013.

ALVIM, A. A. T. B; RONCA, J. L. C. Metodologia de avaliação qualitativa das ações dos comitês de bacias com ênfase na gestão integrada: o comitê do Alto-Tietê em São Paulo. Engenharia Sanitária e Ambiental, v. 12, n. 1, p. 325-334, 2007.

ANA. BRAZILIAN NATIONAL WATER AGENCY. Comitês de Bacia Hidrográfica. 2020. Available at: https:/www.ana.gov.br/aguas-no-brasil/sistema-de-gerenciamento-de-recursos-hidricos/comites-de-bacia-hidrografica

ASSMANN, J. Communicative and cultural memory. In: NÜNNING, A., ERLL, A. (eds.) A companion to cultural memory studies. Berlin: Gruyter, 2010.

BARBOSA, M. C., MUSHTAQ, S., ALAM, K. Integrated water resources management: are river basin committees in Brazil enabling effective stakeholder interaction? Environmental Science and Policy, n. 76, p. 1-11, 2017.

BRASIL. Law 9.433/1997. Creates the National Water Resources Policy and the National Water Resources Management System. Brasília, DF: 1997.

CAMPOS, V. N. O.; FRACALANZA, A. P. Governança das águas no Brasil: conflitos pela apropriação da água e a busca da integração como consenso. Ambiente \& Sociedade, v. XIII, n. 2, p. 365-382, 2010.

CASEY, A. J.; OLIVERA, F. Reflections on organizational memory and forgetting. Journal of Management Inquiry, v. 20, n. 3, p. 305-310, 2011.

CASTREE, N. et al. A Companion to Environmental Geography. Oxford, UK: Blackwell, 2009.

EMPINOTTI, V. L.; JACOBI, P. R.; FRACALANZA, A. P. Transparência e a governança das águas. Estudos Avançados, v. 30, n. 88, p. 63-75, 2016.

ENGLE, N. L., LEMOS, M. C. Unpacking Governance: Building Adaptive Capacity to Climate Change of River Basins in Brazil. Global Environmental Change, v. 20, p. 4-13, 2010. 
FELDMAN, R. M., \& FELDMAN, S. P. What links the chain: an essay on organisational remembering as practice. Organization, v. 13, n. 6, p. 861-887, 2006.

GARDE-HANSEN, J., MCEWEN, L., HOLMES, A., JONES, O. Sustainable flood memory: remembering as resilience. Memory Studies, v. 10, n. 4, p. 384-405, 2017.

GARDE-HANSEN, J., MCEWEN, L., JONES, O. Towards a memo-techno-ecology: mediating memories of extreme flooding in resilient communities. In: HAJEK, A., LOHMEIER, C., PENTZOLD, C. (orgs.) Memory in a mediated world: remembrance and reconstruction. Basingstoke: Palgrave Macmillan, 2015. P. 55-73.

JACOBI, P. R.; PAZ, M. G. A; SOUZA LEÃO, R.; ESTANCIONE, L. M. B. Water governance and natural disasters in the Metropolitan Region of São Paulo, Brazil. International Journal of Urban Sustainable Development, v. 5, n. 1, p. 77-88, 2013.

JACOBI, P. R.; CIBIM, J. C.; SOUZA, A. N. Crise da água na Região Metropolitana de São Paulo - 2013-2015. Geousp - Espaço e Tempo, v. 19, n. 3, p. 422-444, 2016.

JACOBI, P. R.; NASCIMENTO, S. S. Governança ambiental urbana em face das mudanças climáticas. Revista USP, v. 109, p. 133-142, 2016.

JACOBI, P. R.; CIBIM, J.; LEÃO, R. S. Crise hídrica na Macrometrópole Paulista e respostas da sociedade civil. Estudos Avançados, v. 29, n. 84, p. 27-42, 2015.

JACOBI, P. R., MONTEIRO, F. M. Social capital and institutional performance: methodological and theoretical discussion on the Water Basin Committees in Metropolitan São Paulo - Brazil. Ambiente \& Sociedade, v. 9, n. 2, p. 35-54, 2006.

KANSTEINER, W. Finding meaning in memory: a methodological critique of collective memory studies. History and Theory, n. 41, 179-197, 2002.

LANGENMAYR, F. Organisational memory as a function: the construction of past, present and future in organisations. Zurich: Springer, 2016.

LUHMANN, N. Introduction to Systems Theory. Cambridge: Polity Press, 2013.

MARTINS, A. Sistema Cantareira e a crise da água em São Paulo: a falta de transparência no acesso à informação. São Paulo: Artigo 19, 2014.

NISSLEY, N.; CASEY, A. The politics of the exhibition: viewing corporate museums through the paradigmatic lens of organizational memory. British Journal of Management, v. 13, n. 2, p. 35-45, 2002.

NONES, M. Is public participation an added value for river basin management? European Planning Studies, v. 24, n. 6, p. 1159-1174, 2016.

PAHL-WOSTL, C. Water governance in the face of global change: from understanding to transformation. New York: Springer, 2015. 
SANTOS, S. M., SOUZA, M. M. P., BIRCOL, G. A. C., UENO, H. M. River basin management plans and their challenges: the case of the Alto-Tietê River Basin - State of São Paulo, Brazil. Ambiente \& Sociedade, v. 23, p. 1-20, 2020.

SÃO PAULO. Law 7.663/1991. Establishes guidelines for the State Water Resources Policy. São Paulo, SP: 1991.

SUSSKIND, L. Water and Democracy: New Roles for Civil Society in Water Governance. International Journal of Water Resources Development, v. 29, n. 4, p. 666-677, 2013.

TRINDADE, L. L.; SCHEIBE, L. F. Water management: constraints to and contributions of Brazilian watershed management committees. Ambiente $\mathbb{\&}$ Sociedade, v. 22, e02672, 2019.

WALSH, J. P.; UNGSON, P. Organizational memory. Academy of Management Review, v. 16, n. 1, p. 57-91, 1991.

WORCMAN, K., GARDE-HANSEN, J. Social memory technology: theory, practice, action. New York: Routledge, 2016. 


\section{Danilo Rothberg}

\danilo.rothberg@unesp.br

ORCiD: https://orcid.org/0000-0002-3103-8154
Submitted on: 13/10/2020

Accepted on: 09/06/2021

2021;24e:02113

\section{Joanne Garde-Hansen}

\.Garde-Hansen@warwick.ac.uk

ORCiD: https://orcid.org/0000-0003-2462-3790

How to cite: ROTHBERG, D.; GARDE-HANSEN, J. Improving water governance in Brazil: an organisational memory approach.. Ambiente \& Sociedade. São Paulo, v. 24, p. 1-18, 2021. 


\title{
Melhorando a governança da água no Brasil: uma abordagem de memória organizacional
}

\author{
Danilo Rothberg \\ Joanne Garde-Hansen
}

São Paulo. Vol. 24, 2021

Artigo Original
Resumo: Os comitês brasileiros de bacias hidrográficas são uma inovação democrática cada vez mais estudada em todo o mundo como um exemplo positivo de governança da água, com algumas limitações. Em nosso projeto de pesquisa de dois anos (2018-2020), objetivamos ativar, preservar e divulgar narrativas e histórias da participação de vários atores sociais, econômicos e políticos no Comitê da Bacia Hidrográfica do Alto Rio Tietê (São Paulo), para obter memórias organizacionais. Nossos dados de entrevistas trazem lições aplicáveis a contextos com sistemas de governança semelhantes e outros, sugerindo como os arranjos participativos e democráticos podem ser aprimorados como estratégias que uma sociedade pode explorar no processo de aprender a lidar com os efeitos das mudanças climáticas, incluindo a ameaça de escassez de água que cresceu na região metropolitana de São Paulo após 2014. As entrevistas apontam para a necessidade de esclarecimento dos papéis do comitê e de seus membros perante à sociedade, a fim de fortalecer a autoridade e a legitimidade.

Palavras-chave: Governança da água; participação política; memórias organizacionais.

Como citar: ROTHBERG, D.; GARDE-HANSEN, J. Melhorando a governança da água no Brasil: uma abordagem de memória organizacional. Ambiente \& Sociedade. São Paulo, v. 24, p. 1-18, 2021.

DOI: http://dx.doi.org/10.1590/1809-4422asoc20200211r3vu2021L4AO 


\title{
Mejorando la gobernanza del agua en Brasil: un enfoque de memoria organizacional
}

\author{
Danilo Rothberg \\ Joanne Garde-Hansen
}

São Paulo. Vol. 24, 2021

Artículo original
Resumen: Los comités brasileños de cuencas hidrográficas son una innovación democrática que se estudia cada vez más en todo el mundo como un ejemplo positivo de gobernanza del agua, con algunas limitaciones. En nuestro proyecto de investigación de dos años (2018-2020), nuestro objetivo fue activar, preservar y difundir narrativas e historias de la participación de varios actores sociales, económicos y políticos en el Comité de la Cuenca del Río Alto Río Tietê (São Paulo), para obtener memorias organizacionales. Los datos de nuestra entrevista proporcionan lecciones aplicables a contextos con sistemas de gobernanza similares y otros, sugiriendo cómo los arreglos participativos y democráticos pueden mejorarse como estrategias que una sociedad puede explorar en el proceso de aprender a lidiar con los efectos del cambio climático, incluida la amenaza de escasez de agua que creció en la región metropolitana de São Paulo después de 2014. Las entrevistas apuntan a la necesidad de clarificar los roles del comité y sus miembros ante la sociedad, a fin de fortalecer la autoridad y la legitimidad.

Palabras-clave: Gobernanza del agua; participación política; memorias organizacionales.

Como citar: ROTHBERG, D.; GARDE-HANSEN, J. Mejorando la gobernanza del agua en Brasil: un enfoque de memoria organizacional. Ambiente \& Sociedade. São Paulo, v. 24, p. 1-18, 2021.

DOI: http://dx.doi.org/10.1590/1809-4422asoc20200211r3vu2021L4AO 